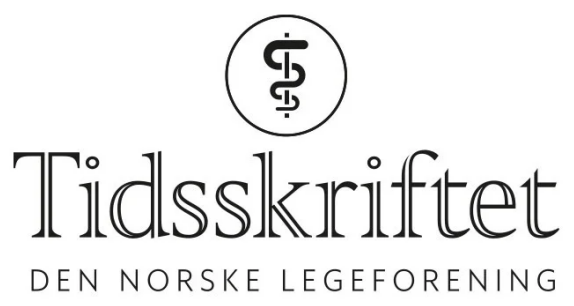

\title{
Kastrasjon av seksualforbrytere?
}

TIDLIGERE I TIDSSKRIFTET

JULIE DIDRIKSEN

julie.didriksen@tidsskriftet.no

Tidsskriftet

I Tidsskriftets utgave nr. 2/1930 kunne vi lese en notis om en tysk artikkel der forfatterne mente å ha løsningen på «et vanskelig seksualproblem». Problemet det er snakk om er seksualforbrytelser, og løsningen er tilsynelatende kastrasjon. Hvorfor? Fordi forbryterens testikler er «syke og avsondrer giftige hormoner». Tidsskriftets redaksjon stilte seg tvilende til konklusjonen i en anmerkning nederst (Tidsskr Nor Lægeforen 1930; 50: 77). 


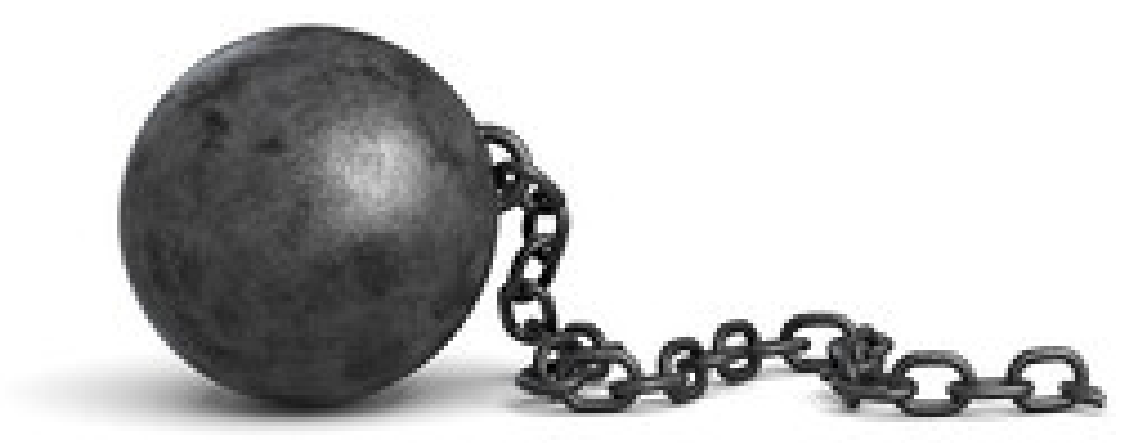

Illustrasjon: Gearstd / iStock

Borters: Løsningen av et vanskelig seksualproblem. Seksualforbrydere ber ofte om å bli kastrert for å bli kvitt den plagsomme abnorme drift, som volder dem så mange lidelser og bekymringer. Lægene er imidlertid lite tilbøielige til å gå med på inngrepet, som de mener strider mot loven. Denne opfatning er feilaktig. Seksualforbrydernes testikler er syke og avsondrer giftige hormoner som er årsaken til at de stadig får tilbakefall tross streng straff. Ofte er det dessuten alkoholisme hos forfedrene. Kastrasjon, mener forf., er prompt virkende og kan ikke erstattes av nogen annen behandling. Seksualforseelser er sterkt $ø$ kende i hele Tyskland.

«Kastrasjon, mener forf., er prompt virkende og kan ikke erstattes av nogen annen behandling»

Forf. meddeler, at en ekshibisjonist som hadde forsett sig en rekke ganger, blev kastrert den 28. februar 1928. Siden har han vært kvitt sin abnorme drift og fikk straffen eftergitt.

(Artikkelen er temmelig ensidig. Den svenske kommisjon som nylig har avgitt betenkning, tar avstand fra kastrasjon på grunn av de psykiske lidelser som inngrepet undertiden medfører. Resultatet er også ofte tvilsomt, da lidelsen oftest er av psykisk art og kjønnskjertlene normale. Herfor taler også de gode resultater som man kan se av hypnotisk behandling. Alkoholisme hos forfedrene spiller neppe nogen rolle i denne forbindelse.

Red. anm.)

(Munch. med. Wochensehr.nr. 40,1929.)

T. Kasa. 
Publisert: 21. september 2021. Tidsskr Nor Legeforen. DOI: 10.4045/tidsskr.21.0285

(C) Tidsskrift for Den norske legeforening 2023. Lastet ned fra tidsskriftet.no 26. april 2023. 